\title{
Distribution of the Increment in Nutrient Element in Humic Allophane Soils of Mt. Kirigamine
}

\author{
by Yoshio INo* and Masami Monsi*
}

Received March 24, 1964

Decomposition rate of the dead organic matter in humic allophane soils of Mt. Kirigamine, Nagano Prefecture, has been studied in a previous paper ${ }^{11}$, in relation to the various factors such as temperature, $\mathrm{pH}$ value and nutrient element level.

In this paper we shall report the changes, which were caused by adding nutrient salts, of the quantity of nutrient elements distributed to three parts of the soil, i. e. microbes, soil solution and mineral particles-humus colloids.

\section{Materials and Methods}

The circulation of inorganic salts in the soil is schematically shown in Fig. 1. The total amount $T$ of an element in the soil can be expressed as follows:

$$
T=O+M+F+I
$$

where $O$ means the amount of a nutrient element contained in organic matter including living tissues, $M$, the amount contained in soil microbes, $F$, the amount directly available for plant growth, contained in soil solution (free phase), $I$, the amount immobilized by mineral particles and humus colloids. When an amount of the nutrient element $\Delta T$ is added to the soil, each amount of $O, M, F$, and $I$ changes $O^{\prime}, M^{\prime}, F^{\prime}$, and $I^{\prime}$, respectively. So,

$$
\begin{aligned}
\Delta T= & \left(O^{\prime}-O\right)+\left(M^{\prime}-M\right)+\left(F^{\prime}-F\right) \\
& +\left(I^{\prime}-I\right)
\end{aligned}
$$

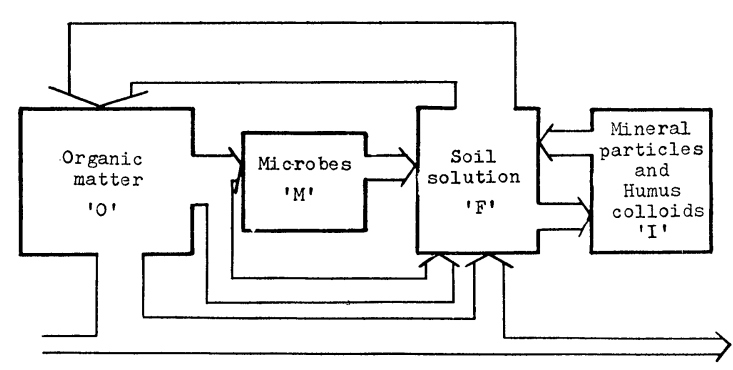

Fig. 1. A diagram of circulation of the inorganic salts in the soil. See the text for the explanation.

With this equation the distribution and movement of the nutrient element added to the soil can be assessed.

Humic allophane soils used for experiments were obtained from the depth of 10$20 \mathrm{~cm}$ of an Arundinella hirta-type grassland community in Mt. Kirigamine (ca. $1600 \mathrm{~m}$ above sea-level), Nagano Prefecture, as described in a previous paper ${ }^{1)}$, in which chemical properties and moisture contents of the sample soils were reported.

Amounts of extractable nitrogen, potassium and phosphorus were measured along with the measurement of $\mathrm{CO}_{2}$ evolution in the $\mathrm{P}-, \mathrm{K}$ - and $\mathrm{KP}$-series ${ }^{1)}$ and in the control.

Extractable nitrogen: A sample soil, $70 \mathrm{~g}$ in fresh weight, was transferred from the $\mathrm{CO}_{2}$ measuring vessel ${ }^{11}$ into a $500 \mathrm{ml}$ conical flask to extract its free-phase nitrogen with $300 \mathrm{ml}$ of $10 \% \mathrm{KCl}$ solution. After a 1-hour shaking on a reciprocating shaker, the soil suspension in the flask was filtered through a glass filter (No. G25) with an

\footnotetext{
* Department of Botany, Faculty of Science, University of Tokyo, Hongo, Tokyo, Japan.
} 
aspirator. With the filtrate the measurement of nitrogen extracted as $\mathrm{NH}_{4}{ }^{+}$was made by the micro-Kjeldahl method.

Extractable potassium and phosphorus: Free-phase potassium and phosphorus were extracted with $300 \mathrm{~m} l$ of $1 \%$ citric acid from the sample soil of $70 \mathrm{~g}$ in a $500 \mathrm{~m} l$ conical flask, which was shaken for 24 hours on a reciprocating shaker. The soil suspension was filtered similarly as in the nitrogen extraction. A part of the filtrate was used to measure potassium content with a flame photometer (Tokyo-Kôden, model 10A) and the remainder was used to measure a phosphorus content colorimetrically ${ }^{2}$.

\section{Results}

1) Extractable nitrogen

The amount of nitrogen extracted in each series is shown in Fig. 2. In the K-1 series and the control where was no addition of $\mathrm{NH}_{4} \mathrm{H}_{2} \mathrm{PO}_{4}$, nitrogen was extracted in a very small amount $(3 \mathrm{mg} \mathrm{N} / 100 \mathrm{~g}$ dry soil). In the $\mathrm{P}-4, \mathrm{P}-2, \mathrm{P}-1$ and $\mathrm{KP}$-series, to which $\mathrm{NH}_{4} \mathrm{H}_{2} \mathrm{PO}_{4}$ was added at a rate of $235 \mathrm{mg}, 117 \mathrm{mg}, 59 \mathrm{mg}$ and $59 \mathrm{mg} \mathrm{N} / 100 \mathrm{~g}$ dry soil respectively, the extracted amount was $203 \mathrm{mg}, 100 \mathrm{mg}, 54 \mathrm{mg}$ and $54 \mathrm{mg} \mathrm{N} / 100 \mathrm{~g}$ dry soil. As the sample soil contained originally extractable nitrogen of $3 \mathrm{mg} \mathrm{N} / 100 \mathrm{~g}$ dry soil, the amount of nitrogen which became not extractable instantly after the $\mathrm{NH}_{4} \mathrm{H}_{2} \mathrm{PO}_{4}$ addition was calculated to be $35 \mathrm{mg}$ in the $\mathrm{P}-4,20 \mathrm{mg}$ in the $\mathrm{P}-2$, and $8 \mathrm{mg}$ in the $\mathrm{P}-1$ and $\mathrm{KP}$-series. These values correspond to $15 \%, 17 \%$ and $14 \%$ of the added nitrogen, respectively. Since the most of the added $\mathrm{NH}_{4} \mathrm{H}_{2} \mathrm{PO}_{4}$ had not to be absorbed by soil microbes instantly after the addition, these decreases could be attributed to the adsorption of nitrogen by mineral and humus colloids in the soil.

Time trends of the amount of extractable nitrogen showed remarkable difference among the series. One day after starting the experiment, the amount of extractable nitrogen increased extremly in the $\mathrm{P}-2$ and $\mathrm{P}-4$ series, but slightly in the $\mathrm{P}-1$ and

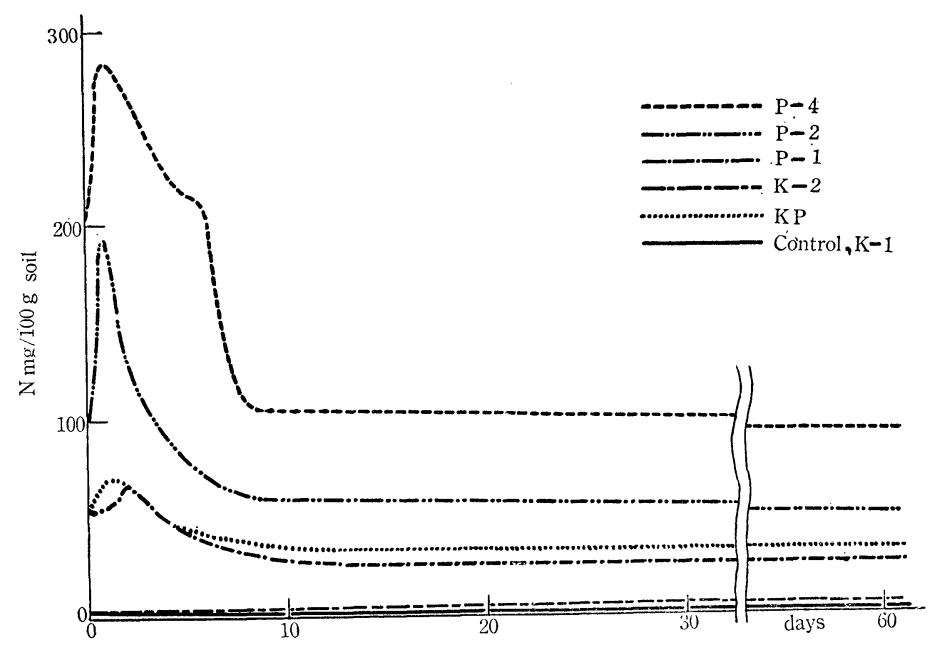

Fig. 2. Effects of $\mathrm{K}$ - and P-salt supply in soils on variation with time of the amount of extractable nitrogen. At $20^{\circ}$. P-1, soils to which $1.3 \mathrm{mg} \mathrm{P} / 100 \mathrm{~g}$ dry soil added; $\mathrm{P}-2,2.6 \mathrm{mg} \mathrm{P} ; \mathrm{P}-4,5.2 \mathrm{mg} \mathrm{P}$; $\mathrm{K}-1,1.3 \mathrm{mg} \mathrm{K} ; \mathrm{K}-2,2.6 \mathrm{mg} \mathrm{K}$; KP, $1.3 \mathrm{mg} \mathrm{K}+1.3 \mathrm{mg}$. 
KP-series. Afterwards the high amount decreased rapidly and finally attained a constant value, $93 \mathrm{mg} \mathrm{N} / 100 \mathrm{~g}$ dry soil in the $\mathrm{P}-4,52 \mathrm{mg}$ in the $\mathrm{P}-2,26 \mathrm{mg}$ in the $\mathrm{P}-1$, and $34 \mathrm{mg}$ in the KP-series. The rapid increase of extractable nitrogen in the initial stage may be caused by accelerated activity of soil microbes accompanied with increasing $\mathrm{CO}_{2}$ evolution ${ }^{1)}$.

In order to determine by bioassay the amount of available nutrient elements which were released by the decomposition of organic matter in soils, seedlings of Nicotiana tabacum, "Bright Yellow" were planted in humic allophane soils incubated for 50 days, at $2^{\circ}, 10^{\circ}$ and $30^{\circ}$, respectively. These plants were grown in a growth box, at $20^{\circ}$, under continuous illumination of 5000 lux for 40 days. These plants were stunted and had almost same dry weights. Clear differences among these plants were, however, shown in nitrogen content which was determined on 10,20, 30 and 40th days after transplanting (Fig. 3). The high-temperature incubation of the soil brought about the high content of total nitrogen of the plant because of increased amount of nitrogen absorbable to the plant or of free-nitrogen in soil.

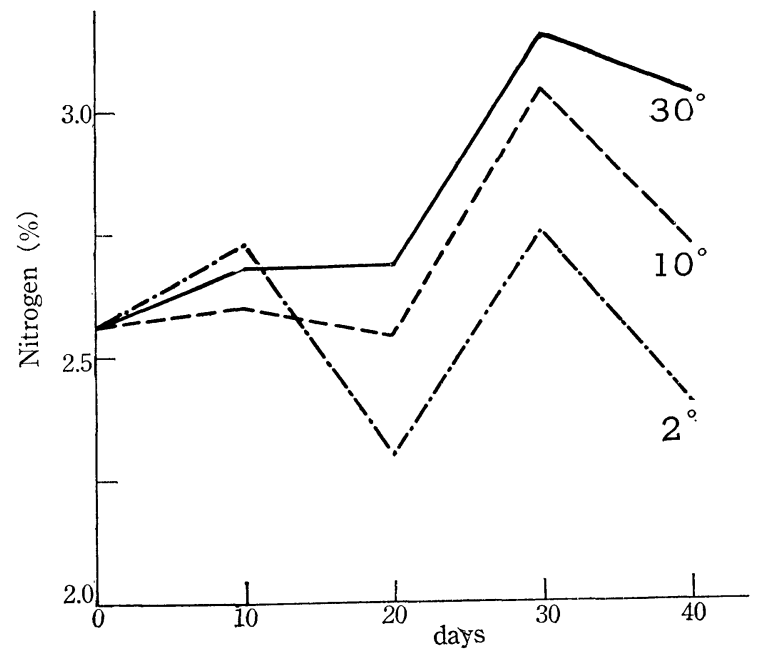

Fig. 3. Time trend of total nitrogen content (\% on a dry weight basis) of tabacco plants which were grown under a condition of $20^{\circ}$ and 5000 lux, on soils incubated for 40 days at $2^{\circ}, 10^{\circ}$ and $30^{\circ}$.

Thus it seems probable that the initial increase of the available nitrogen in the soil was primarily due to the increased inorganic nitrogen that was liberated from organic matter decomposed by soil-microbes of which activities were risen by addition of inorganic salts, especially of phosphate. Interesting is also the fact that the rapid decline which followed immediately after the initial increase of extractable nitrogen was accompanied with rapid increase in number of soil fungi. This may suggest that nitrogen assimilation by soil fungi and other microbes was highly responsible for the decrease in extractable nitrogen.

2) Extractable potassium

At the beginning of the incubation experiment, extractable potassium decreased gradually in the control but it increased slightly in the P-4 series $(8.2 \mathrm{mg}$ on the 15th day and $9.6 \mathrm{mg}$ on the 30 th day). Time trends of extractable potassium measured in the $\mathrm{K}-1$ and $\mathrm{K}-2$ series to which potassium was added as $\mathrm{KCl}$ respectively at a rate 
of $138 \mathrm{mg}$ and $225 \mathrm{mg} \mathrm{K} / 100 \mathrm{~g}$ dry soil, are presented in Fig. 4. After a rapid decrease of the extractable potassium content occurred 2 to 4 days after starting the experiment, the extractable potassium in the $\mathrm{K}-1$ and $\mathrm{K}-2$ series showed mild increase, and reached nearly a constant level of $97 \mathrm{mg} \mathrm{K} / 100 \mathrm{~g}$ dry soil in $\mathrm{K}-1$ on the 15 th day and of $180 \mathrm{mg} \mathrm{K}$ in $\mathrm{K}-2$ on the 45th day. The amount of potassium adsorbed by humus and mineral particle colloids just after the adding of potassium salt was $38 \mathrm{mg} \mathrm{K}$ in the $\mathrm{K}-1$ and $36 \mathrm{mg} \mathrm{K}$ in the $\mathrm{K}-2$ series. The proportions of these amounts, or losses from added amounts, to the total potassium amounts added were $28 \%$ in the $\mathrm{K}-1$ and $16 \%$ in the $\mathrm{K}-2$ series.

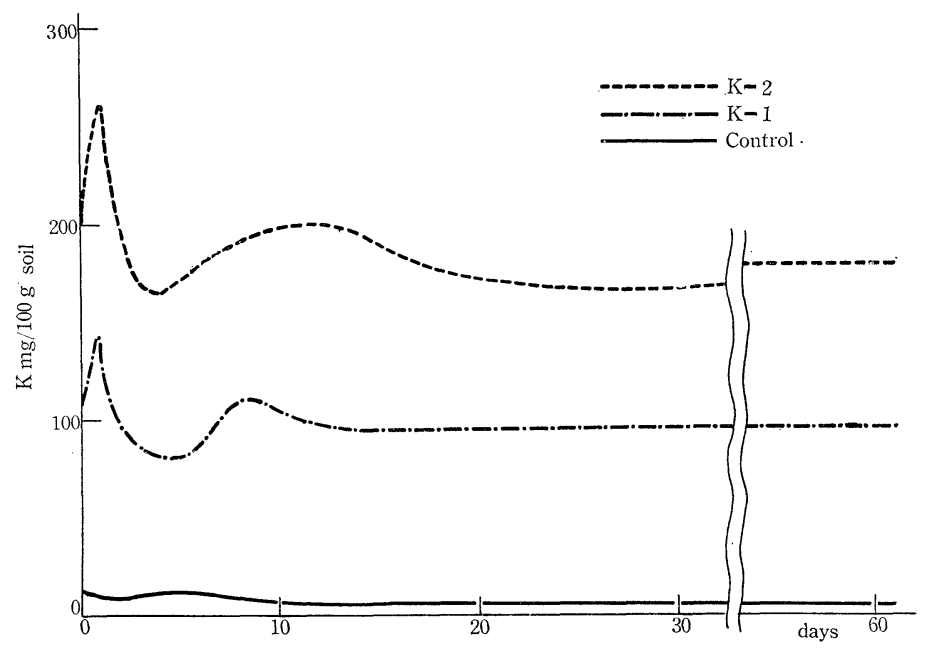

Fig. 4. Effects of K-salt supply in soil on the variation with time of the amount of extractable potassium. At 20. Indications as in Fig. 2 .

3) Extractable phosphorus

Throughout the experimental period, no extractable phosphorus was detected in the control soil samples as well as in the K-series, though these soil samples had high content of total phosphorus (Table 1, in a previous paper ${ }^{1)}$ ). Time trends of extracted phosphorus in the $\mathrm{P}$-series, which inorganic phosphorus was added to at the rate of $550 \mathrm{mg}$ in the $\mathrm{P}-4,275 \mathrm{mg}$ in the $\mathrm{P}-2$ and $138 \mathrm{mg} \mathrm{P} / 100 \mathrm{~g}$ dry soil in the P-1 series, are presented in Fig. 5. Amount of extractable phosphorus showed a sudden increase at the beginning of the experiment, but afterwards it decreased rapidly to reach nearly constant values. The well-known fact that humic allophane soils adsorb a large quantity of phosphorus was also recognized clearly in this experiment. The amount of loss of the added phosphorus by this adsorption was determined to be $323 \mathrm{mg}, 206$ $\mathrm{mg}$ and $106 \mathrm{mg} \mathrm{P} / 100 \mathrm{~g}$ dry soil for the $\mathrm{P}-4, \mathrm{P}-2$ and $\mathrm{P}-1$ series. These values correspond respectively to $59 \%, 75 \%$ and $77 \%$ of the total phosphorus supplied.

Magnitudes of the changes in extractable phosphorus in the early stage of the incubation were significantly large in the $\mathrm{P}-4$ and $\mathrm{P}-2$ series as compared with the $\mathrm{P}-1$ series. This suggests that the liberation of phosphate from organic matters in the soil and the fixation of the phosphate by soil microbes might be largely accelerated by the addition of inorganic phosphorus into the soil. 


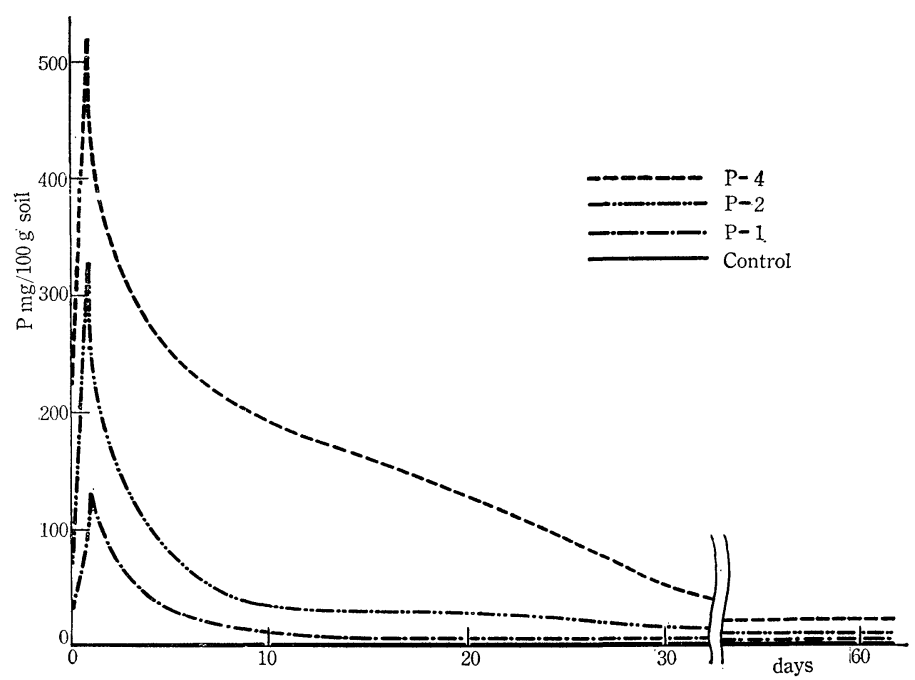

Fig. 5. Effects of $\mathrm{P}$-salt supply in soils on the variation with time of the amount of extractable phosphorus. At $20^{\circ}$. Indications as in Fig. 2.

\section{Conclusion}

By using equation 2, distribution of the increment in nutrient element to three components, the part in available form, the part immobilized by adsorption with humus and mineral colloids, and the part in organic form, was determined for nitrogen, potassium and phosphorus from the results of the measurement of extractable inorganic salts. Proportions of these three parts to the total increment are summarized in Table 1 , in the P-, K- and KP-series. Percentage of phosphorus immobilized by adsorption of soil colloids was $59 \%$ in the $\mathrm{P}-4$ plot, and $77 \%$ in the $\mathrm{P}-1$ plot as well as in KPseries. The corresponding percentages for nitrogen and potassium were relatively small. As the allophane and humus colloids have rather small adsorption activities for

Table 1. Distribution of the increment in nutrient element in soil (\%).

\begin{tabular}{c|c|c|c|c}
\hline \multirow{2}{*}{ element } & sample & free phase & $\begin{array}{c}\text { non-biotic } \\
\text { immobilization }\end{array}$ & $\begin{array}{c}\text { biotic } \\
\text { immobilization }\end{array}$ \\
\hline \multirow{3}{*}{ nitrogen } & P-1 & 39 & 14 & 47 \\
P-2 & 41 & 17 & 42 \\
P-4 & 38 & 15 & 47 \\
KP & 53 & 14 & 33 \\
potassium & K-1 & 70 & 28 & 2 \\
& K-2 & 80 & 16 & 4 \\
& P-1 & 7 & 77 & 20 \\
phosphorus & P-2 & 5 & 75 & 37 \\
& P-4 & 3 & 77 & 20 \\
\hline
\end{tabular}


monovalent ions, a small amount of $\mathrm{NH}_{4}{ }^{+}$or $\mathrm{K}^{+}$is generally immobilized with these colloids.

Nitrogen, potassium and phosphorus contents in the soil and annual absorption by plants of each nutrient element in an Arundinella hirta-type community in Mt. Kirigamine were as follows (total carbon amounted to $26.19 \mathrm{~kg} / \mathrm{m}^{2}$, and mean $\mathrm{C} / \mathrm{N}$ ratio was ca. 15):

total amount in soil $\left(\mathrm{g} / \mathrm{m}^{2}\right)$ extractable amount $\left(\mathrm{g} / \mathrm{m}^{2}\right)$ annual absorption by plants $\left(\mathrm{g} / \mathrm{m}^{2} / \text { year }\right)^{3)}$

$\begin{array}{ccc}\text { nitrogen } & \text { potassium } & \text { phosphorus } \\ 1737 & 383 & 575 \\ 9.1 & 11.9 & 0.2 \\ 3.5 & 4.5 & 0.38 .\end{array}$

These results may demonstrate that the plants and microbes are more difficult to absorb phosphorus than nitrogen and potassium in humic allophane soils of Mt. Kirigamine, though a quite large amount of total phosphorus could be measured in the soils.

\section{Summary}

The movements of nutrient elements in humic allophane soils of a grassland dominated by Arundinella hirta in Mt. Kirigamine ( $1600 \mathrm{~m}$ above sea-level), Nagano Prefecture were investigated.

The distribution of the increment of nutrient elements added to the soil to (a) the part in free form ( $F$ in Eq. 1), (b) that adsorbed and immobilized by mineral particles and humus colloids $(I)$, and (c) that in organic form $(O+M)$, was estimated as to nitrogen, potassium and phosphorus. Phosphorus was immobilized in high percentages, $59-77 \%$ on the amount of the total increment, while potassium as well as nitrogen was immobilized rather in low percentages. Nitrogen, potassium and phosphorus in free form were $38-53 \%, 70-80 \%$ and $3-7 \%$ on the amount of each increment.

\section{References}

1) Ino, Y., and Monsi, M., Bot. Mag. Tokyo 77: 158 (1964). 2) Chapman, H. D., and Pratt, P. F., Method of Analysis for Soils, Plants and Waters (University of California, California, 1961).

3) Midorikawa, B., et al., Report for the Improvement of the Kirigamine Pasture (Japanese: Division of Agriculture, Nagano Prefecture, Nagano 1963).

\section{摘要 \\ 伊野良夫·門司正三：霧ケ峰の腐植質アロフェン土壤における添加した 栄養元素の配分について}

火山灰土壇は寒冷地で酸性の性質を示し, 供給された多くの栄養塩類を非有效態にかえることが報告さ

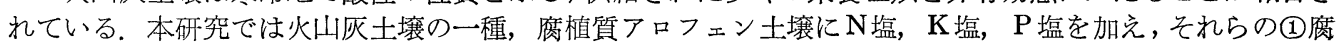
植や鈗物コロイドに吸着される部分, (2)土壌中の微生物など生物体の構成分となる部分, (3遊離態として土 壌溶液中に加わる部分への配分比率を調べた。塩類添加量の多少によって配分比率はいくらか增減するが， $\mathrm{N}$ は增分の $38 \sim 53 \% ， \mathrm{~K}$ は 70 80\% が遊離態として残るが， $\mathrm{P}$ はわずか 3 7\% が遊離態として残り， $70 \%$ 以上は腐植や鉣物コロイドに塩類添加後すぐに吸着されることが推定された。本土壇に生育する植物 にとって $\mathrm{P}$ はきめて吸収しにくい栄養元素であると思われる。（東京大学理学部植物学教室） 